\title{
El Niño Storms Erode Beaches on Monterey Bay, California
}

\begin{abstract}
s recently as 1998, storms generated by El Niños severely eroded beaches along Monterey Bay, California. To better understand the effects of such storms, United States Geological Survey (USGS) scientists, in cooperation with the California Department of Parks and Recreation, have been actively monitoring changes in the foreshore since the mid-1980's. The results of this study will help protect coastal residents, property, and environments and are being used by the State of California in guiding the management of public beaches.
\end{abstract}

Intense storms often produce abnormally high waves and elevated sea level, causing extensive beach erosion and shoreline retreat. The worst erosion generally occurs when multiple storms hit during periods of especially high tides. Several years may pass between storms intense enough to cause shoreline erosion that results in significant widespread damage. Although waves rebuild beaches after such storms, this seaward accretion may not return a beach to its pre-storm position, requiring coastal-zone managers to consider whether to take remedial measures.

During the winters of 1982-83 and 1997-98, two of the most severe El Niños of the 20th century produced intense storms that pounded central California. These storms followed more southerly tracks than usual and combined with periods of high tides to intensify the normal winter erosional cycle, causing tens of millions of dollars in damage along the central California coast. On Monterey Bay, coastal cliffs, dunes, and manmade structures suffered serious damage, much

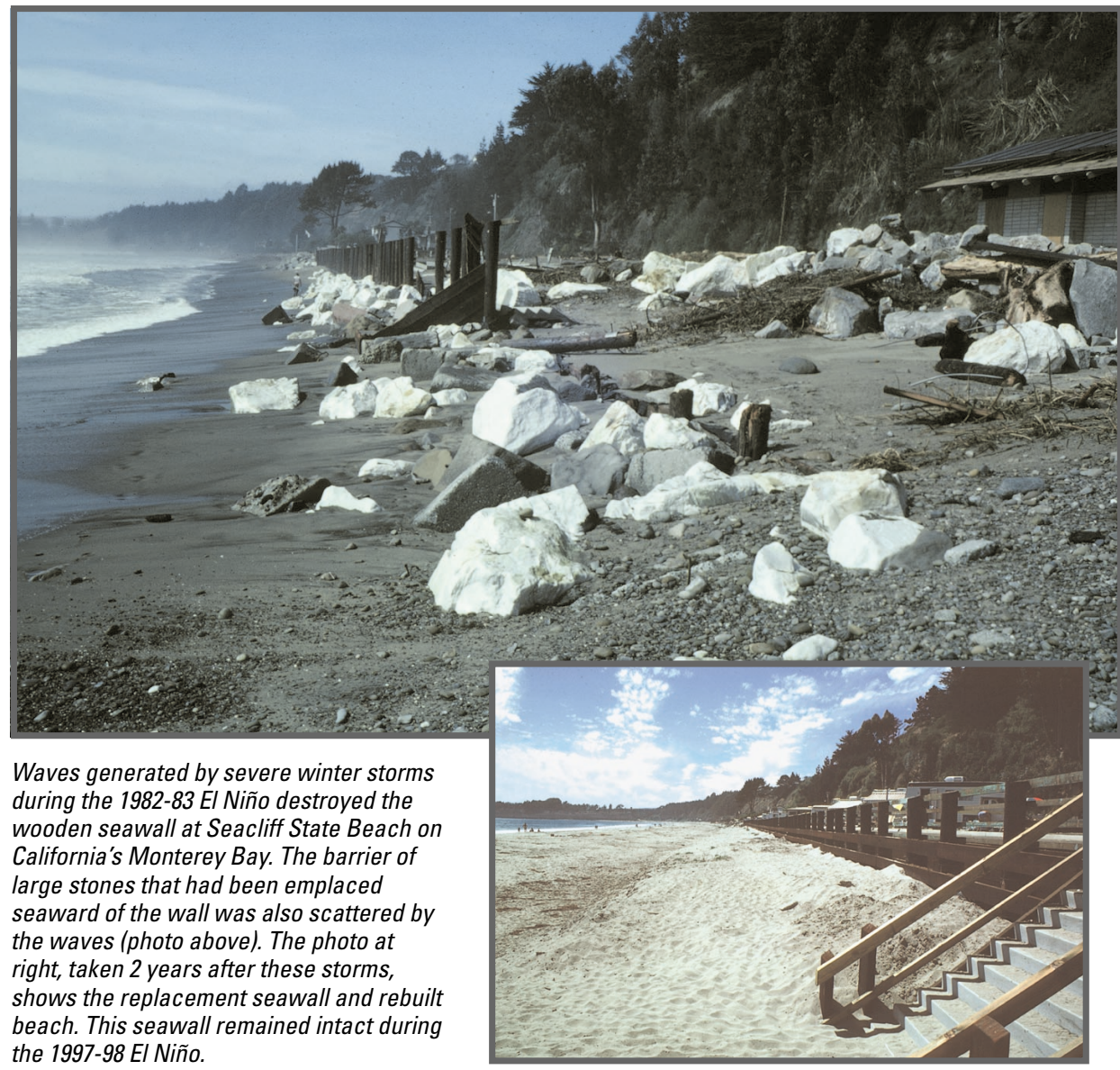

of it along the northern, most populated part of the bay. To better understand the effects of such storms, United States Geological Survey (USGS) scientists, in cooperation with the California Department of Parks and Recreation (DPR), began actively monitoring changes at nine California State Beaches on Monterey Bay in 1983 and at four additional ones in 1985.

The extent of beach erosion or accretion is measured by landward or seaward shifts in the position of the shoreline at mean sea level (MSL). Storm waves during the 1982-83 El Niño had stripped large volumes of sand from Monterey Bay beaches, leaving beachfront homes and coastal cliffs and dunes exposed to direct wave attack. By the end of the 1982-83 El Niño storms, Monterey Bay beaches were distinctly narrower than before. For 2 years, normal wave activity deposited sand, rebuilding the beaches. However, there is no way of knowing whether the beaches returned to near their pre-El Niño states, because no data had been collected on their profiles before 1983. In succeeding years, the beaches went through several erosional and depositional cycles. From 1985 through September 1997, all but two Monterey Bay beaches remained stable except for normal seasonal fluctuations.

During the 1997-98 El Niño, several intense winter storms from the south struck the Monterey Bay coastline. However, beach erosion along the bay was less than in the 1982-83 El Niño, and not a single Monterey Bay beach was eroded so severely in 1997-98. For example, at Seacliff State Beach on the northeast coast of the bay, which is most susceptible 
MONTEREY BAY STATE BEACHES AND THE EXTENT OF EROSION AND ACCRETION DURING 1983 TO 1998

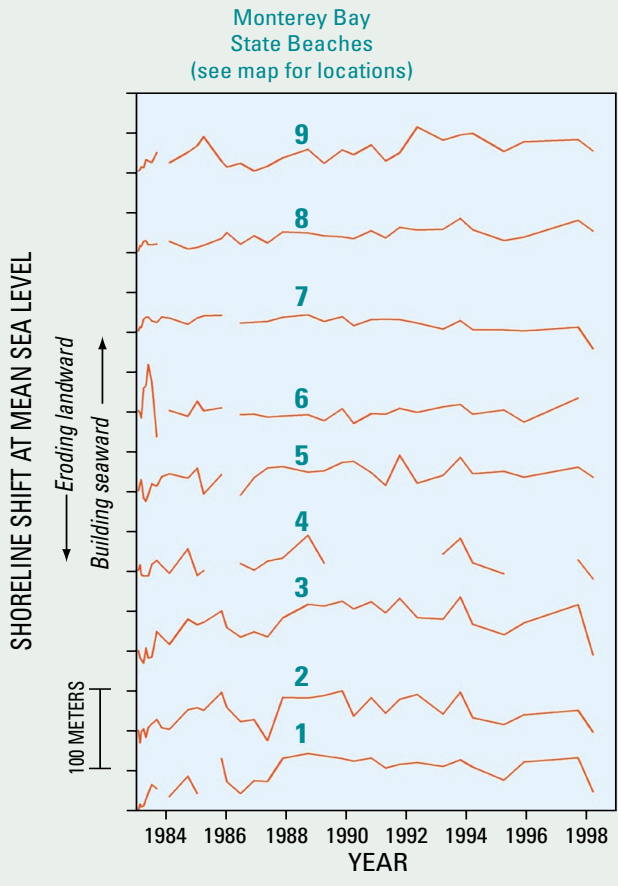

The extent of beach erosion or accretion is measured by landward or seaward shifts in the position of the shoreline at mean sea level (MSL). Storm waves during the 1982-83 El Niño had stripped large volumes of sand from Monterey Bay beaches, leaving beachfront

homes and coastal cliffs and dunes exposed to direct wave attack. By the end of the 1982-83 El Niño storms, Monterey Bay beaches were distinctly narrower than before. U.S. Geological Survey scientists, in cooperation with the California Department of Parks and Recreation, began actively monitoring changes at nine Monterey Bay beaches in February 1983 and at four additional beaches along the bay in 1985. During the 1997-98 El Niño, several intense winter storms eroded beaches along the bay, though not as severely as the 1982-83 El Niño storms.

to waves from the south, erosion during the 1997-98 El Niño was no more severe than during some non-El Niño years.

Only two beaches appear to have undergone net retreat since 1983. One, Moss Landing State Beach, is adjacent to the head of Monterey Submarine Canyon, a factor that complicates interpretations of long-term shoreline retreat because sand eroded from the beach may move down the canyon and be lost to the deep sea. The other, Fort Ord Beach, is narrow and backed by a high, but easily eroded, cliff. In most years, winter storm waves erode the beach to the extent that they can attack the cliff. Consequently, the shoreline has retreated an average of 1 to 2 yards (meters) per year since USGS monitoring began in 1983. However, the summer beach continues to maintain nearly the same shape and width as it migrates landward.

The cooperative efforts of USGS scientists and the DPR at Monterey Bay's beaches have led to a better understanding of how these beaches change during both El Niño and non-El Niño years. The results of these ongoing studies are being used by the

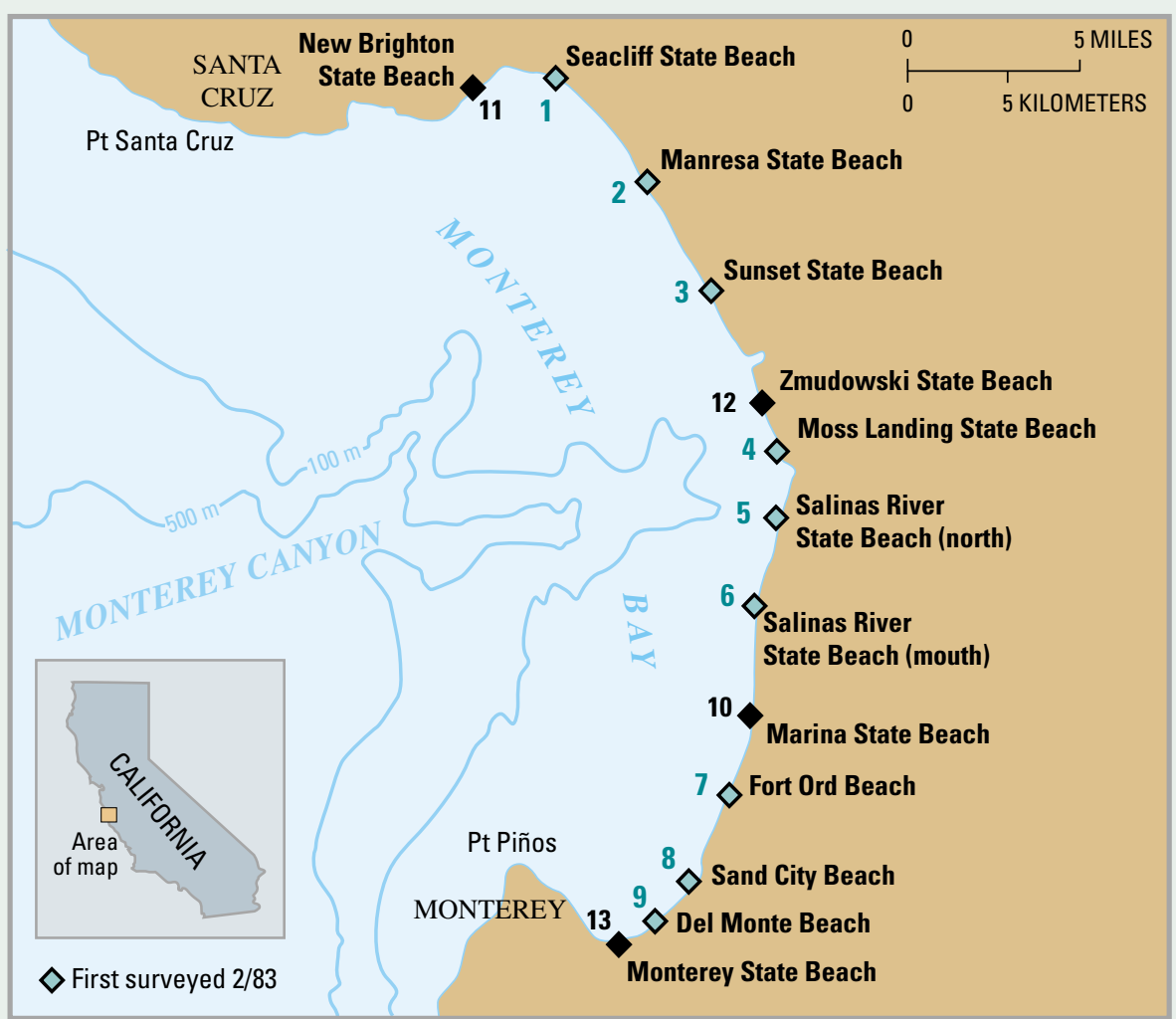

${ }_{2} \diamond^{\text {Manresa State Beach }}$

$\diamond$

$\checkmark$ Salinas River

Salinas River

State Beach (mouth)

Marina State Beach

$\diamond$ Fort Ord Beach

Monte Beach

Monterey State Beach 